cooperation more long-term", Dr Buschendorf explained. "Under the present agreement it is difficult to get the right partners for scientific cooperation".

From the German point of view, the situation was somewhat improved by the signing, last May, of an agreement for the exchange of scientists, between the Royal Society and the GDR Academy of Sciences. Otherwise, however, they remain intransigent that what they need is a separate cooperation for science. They do not even seem willing to discuss possible areas of cooperation until such an agreement is signed - even to suggest subjects, Dr Buschendorf feit, would be "premature". It is known, however, that the British side has put forward a number of concrete proposals for joint seminars and visits, in order to bring together specialists who could then discuss feasible cooperation programmes. Subjects in which Germans have indicated particular interest include industrial hydraulics and corrosion protection. So far, however, there has been no firm response.

The insistence of the GDR on keeping science and trade firmly separated seems a little incongruous in the light of its own science policy. This, according to the official hand-outs for the current anniversary, is based on "a close and desired connection" between research and "the tasks set in the national economy". Innovation and implementation are the keynotes, and workers at all levels are encouraged to suggest further possible improvements. There are close funding links between industry and basic research. The production of university graduates is also a part of state planning, and each student is provided with his or her future job at least a year before graduation.

Given an economic structure, where "all the planning of scientific and technological work is based on the requirements put on the development of the national economy", it is difficult to understand the Germans' reluctance at least to explore what can be done under the existing agreement. Many of the fields which have priority in the GDR research programme - environment, water pollution, energy and raw materials, computers, could provide considerable scope for joint work with the UK or other western countries.

Perhaps some part of the explanation may lie in a report produced last spring by the East Berlin Institute for Politics and Economics. The Institute team, it appears, was apprehensive that injudicious importing of licenses could harm indigenous research and development by turning the national research potential into a mere mechanism for the adaptation of foreign thinking.

So far, however, no negotiators have made any reference to this point of view, but, on the thirtieth anniversary of GDR statehood, have raised yet again their plea for a separate scientific agreement.

Vera Rich

\title{
Soviet scientist proposes Siberian sites for nuclear power stations
}

Soviet nuclear power stations should be sited in remote regions of Siberia and the Far North, according to Academician Nikolai Dollezhal' a leading nuclear scientist, and Yurii Koryakin, a Doctor of Economic Sciences. Moreover, such power stations should take the form of large "nuclear energy complexes", each consisting of a number of power stations of "several tens of millions of kW capacity" together with fuel reprocessing plants, and possibly facilities for utilising nuclear byproducts.

This proposal, which the authors themselves admit is "radical", appeared in the September issue of Kommunist, the leading Party theoretical journal. Starting out apparently as an encomium of Soviet nuclear progress, the tone gradually becomes less optimistic, and, after outlining the setbacks and delays of the fast breeder programme, the authors openly tackle the environmental problems, hitherto dismissed by Soviet publicists as scare-mongering by capitalist oil interests. Reprocessing risks are particularly stresed, and bolstered by the assertion that basic reprocessing costs are "significantly" higher than originally estimated.

Still more costly, they imply, is the loss in the productive land and water resources. Some $60 \%$ of the Soviet population live west of the Volga river/Volga-Baltic canal

\section{Physicist flown home to face charges}

Franco Piperno, the Italian physicist who had asked for political asylum in France, was extradited to Italy last week. The extradition order was given a week in advance of its scheduled hearing to avoid demonstrations and rescue attempts.

Piperno, aged 36, was escorted from Sante prison at $7 \mathrm{am}$ to Le Bourget Airport where an Italian Air force plane took him to the small military airfield, Practica di Mare, north of Rome. He was whisked to solitary confinement in the political wing of the modern Revibbia jail in Rome.

Students in Rome set fire to cars and buses to protest at Pierno's extradition from France and police fired volleys of tear gas in unsuccessful attempts to disperse the demonstrators.

Forty five counts of extradition ranging from stealing car license plates to armed insurrection and including offences against the highway code were rejected by the French Court of Appeal (as was a first extradition request) on the grounds that they were political in character and violated the 1870 extradition treaty between the two countries.

But the court released Piperno to the Italian authorities to answer charges that he had sheltered two men in whose homes Italian police had found guns allegedly line. It is here, in the main area of industrial and agricultural production that it is currently proposed to site nuclear power stations. The annual water requirements of nuclear and thermal power-stations already exceed $100 \mathrm{~km}^{3}$, some $2 \mathrm{~km}^{3}$ of which are "irreversibly" lost. To accommodate this water, by the end of the century, if current construction patterns continue, agricultural land sufficient to provide bread for "several million people", will have been sacrificed.

Dollezhal' and Koryakin would not, they stress, cast any doubt on the "historical necessity" of nuclear energy. Without nuclear energy, they affirm "it is impossible to construct the energy basis of developed socialism".

Giant energy complexes in Siberia, they claim, might well prove to be more efficient as regards construction, operation, and the "utilisation of labour reserves". Environmental hazards would be removed to a safe distance, and those associated with the transport of fuel from reactor to reprocessing plant eliminated completely. Finally - and this might well be the point that would win over the decision makers the proposed nuclear complexes could be integrated into the Soviet Union's most prestigious civil engineering project - the diversion of the Siberian rivers to replenish the arid south.

Vera Rich

used in the abduction of Aldo Moro. Moro, one of Italy's political elder statesmen, was kidnapped and later killed by the Red Brigade guerrilla group in Rome after their attempts to exchange him for jailed comrades had failed.

Piperno had denied involvement in the Moro affair. His statement at the extradition hearing was: "Perhaps it is better this way. At least I will be able to confront quickly that which in Italy is called justice and to demonstrate that I was not involved in the Moro kidnapping and assasination."

In Paris, where Piperno had received widespread support, French commenators expressed dismay and anger at the extradition. Francois Mitterand, leader of the Socialist opposition, declared that the Socialist Party "deplores the fact that French judges have yielded to governmental pressures". And Phillipe Boucher, writing in Le Monde, said: "It is plainly unreasonable to believe that Italy had no political interest in brandishing Piperno as proof of their determination to combat terrorism. No one can seriously maintain the contrary ... The (judicial) method in this case is contestable, indeed unseemly. It is furthermore dangerous." 